\title{
HISTORICAL INFORMATION ON KHARKIV REGIONAL SPECIALIZED INFANT ORPHANAGE: ONE HUNDRED YEARS
}

\author{
Marabyan R. ${ }^{1}$, Gonchar M. ${ }^{2}$, Riga O. $^{2}$ \\ Kharkiv Regional Specialized Infant Orphanage No.1, Kharkiv, Ukraine ${ }^{1}$ \\ Kharkiv National Medical University, Kharkiv, Ukraine ${ }^{2}$
}

\begin{abstract}
The article presents historical data, which are currently known, on the organization and transformation with the time of the public health institution "Kharkov Regional Specialized Child Home No.1". Modern approaches to accompanying children not only of orphans, but also children with special needs are presented: rehabilitation, early intervention services, pediatric palliative care. As the clinical base of the Kharkiv National Medical University, the institution carries out an educational program for the training of students, interns, clinical residents, educational work, scientific work, which is represented by a large number of participation in national and international conferences and congresses, publications, thesis, internship.
\end{abstract}

KeyWords: Kharkiv Regional Specialized Child's Home, Kharkov National Medical University, children of early age.

Kharkiv Regional Specialized Infant Orphanage No. 1 (Infant Orphanage) is a health care institution, which provides medical, social, and palliative care for young children who have been left without parental authority, as well as children who are brought up in families [1].

Specialists of different fields work in the infant orphanage. There are doctors, nurses, special educators, speech therapists, psychologists.

The Infant Orphanage is one of the oldest in Ukraine and was founded approximately in 1918 by the decree of Nadezhda Krupskaya and it was situated in 3 Revolution street; it started functioning as the Infant Orphanage No.7 of the City Health Department.

During the Second World War and occupation, all children were brought up under the supervision of the remaining employees, who preserved the records of the children's movement, books of orders (according to the senior worker of the Infant Orphanage N.E. Sitnikova).

\section{Corresponding author:}

Olena Riga, MD, PhD, Professor of Pediatrics No.1 and Neonatology Department, Khharkiv National Medical University, Ukraine.

E-mail: yeletskayaelena@gmail.com
Upon liberation of Kharkiv from GermanFascist invaders on 23 August, 1943, the Infant Orphanage was moved to 47 Artema street and was named "Regional Specialized Infant Orphanage No 1" of the Regional Health Department, where the children of soldiers who died in the war were brought up.

In 1945 a similar institution at the Infant Orphanage was created in a suburb of Kharkiv, in the village of Zeleniy Gai.

The Board of Trustees, which was established on 7 September, 1945 functioned at the Infant Orphanage from 1945 to 1955, and it conducted its work according to the Statute of the Board of Trustees, approved by the USSR Ministry of Health on 15 August, 1945.

In January 1956, the prefix "specialized" in the documents was omitted and the name Kharkiv Infant Orphanage of the Regional Health Department appeared

In 1972 the Infant Orphanage moved to a new premise in 9 Rybalko street Kharkiv, where it has been situated until now.

By the order of the Directorate of Health of Kharkiv Regional State Administration as of 26.06.2001, the Infant Orphanage was given a specialized status, and it was renamed as "Kharkiv Regional Specialized Infant Orphanage No 1" [3]. 
Groups of medical and social rehabilitation for children with special needs and Early Intervention Service have been functioning in the Infant Orphanage since 2010 (Fig. 1, Fig. 2).

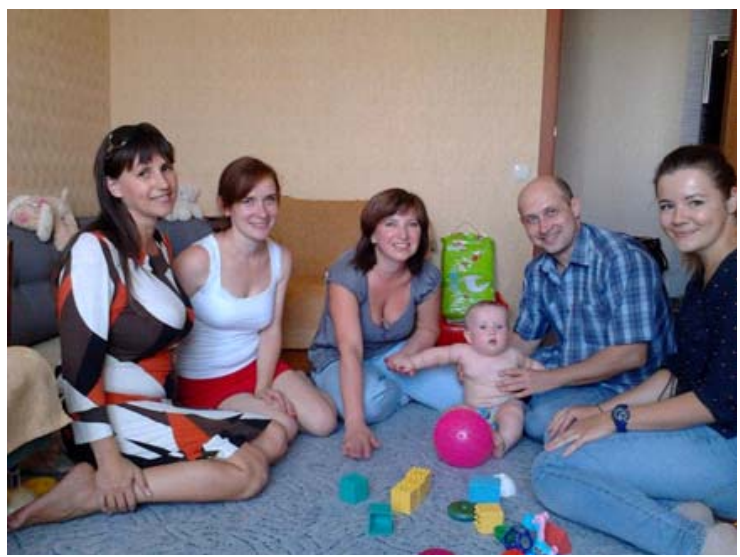

Fig. 1. Individual rehabilitation of a disabled child

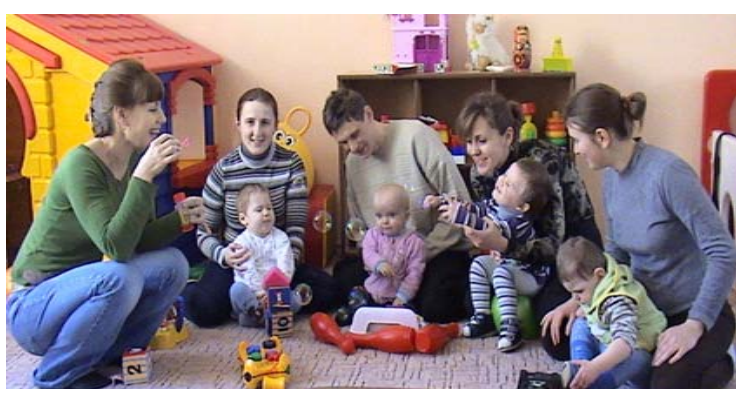

Fig. 2. Group rehabilitation of disabled children with parents

On 29 January, 2018 the department of palliative care for children was founded, the five new separate chambers for children and their relatives were opened. The World Health Organization defines the pediatric palliative care as follows: "Active integrated care for body, mind and spirit of child and his family" [4-7].

Palliative care starts when the child is diagnosed with an incurable disease, continues regardless of whether the child's illness is directly treated and it requires a versatile, multidisciplinary approach. The first in Ukraine palliative mobile teams start working at patient's home [8] (Fig. 3).

Principles of palliative care consist of : 1) improving the quality of the child's life and his family; 2) involving the child and his family to identify needs; 3) provide all necessary medical, psychological, cognitive, educational, entertaining and educational resources; 4) provide round-the-clock care with the help of qualified specialists of the healthcare system, complementing each other's functions [6-11].

The Infant Orphanage No 1 has become the first home for seven thousand orphans for nearly century-long history.

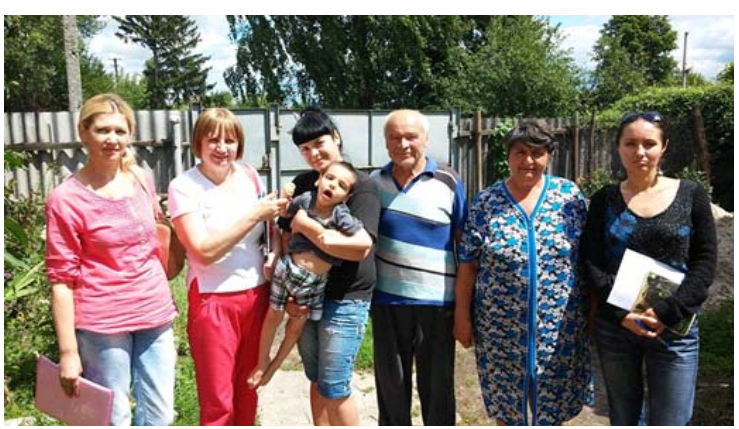

Fig. 3. Pediatric palliative mobile team

Doctors and educators of the Infant Orphanage are convinced and sincerely support the idea that the family is the only place where a child can be really happy and healthy. The most important thing that all the infants who live in the Infant Orphanage need is a huge amount of human care and attention.

Since 2008, the Infant Orphanage has been a teaching clinic of the Department of Pediatrics No. 1 and Neonatology. It trains Ukrainian and English-medium six-year students, interns, clinical residents etc.

It also develops educational work with students as volunteers.

Physicians of Infant Orphanage have completed $3 \mathrm{Ph}$.D. theses and one is being written:

- R. V. Marabyan Optimization of malnourishment diagnostic tools in early age children with paralytic disorders (2015);

- A.Yu. Pen'kov Improving of prevention of health status in children with paternal deprivation by determining the effect of stress hormones on development. - Manuscript (2015);

- I.V. Gordienko Diagnosis and prediction of physical disorders, neuro-mental development of young preterm children. (2017);

- N.M. Konovalova Diagnosis of developmental disorders and optimization of rehabilitation of young children from mothers with alcohol exposure.

There are more than 90 publications (articles and abstracts), 7 educational and tutorial recommendations, 1 monograph, as a result of teamwork.

There were four participations in Salzburg CHOP Seminar of Open Medical Institute (American Austrian Foundation) in 2009, 2013, 2017.

The results of cooperative work were introduced on 36 congresses, conferences, forums in Ukraine and include the following:

- Congress of the European Academy of Pediatrics (Lyon, France, 2013);

- De-institualisation Project of IC Lumos (London, Great Britain, 2013); 
- $5^{\text {th }}$ Congress of the European Academy of Pediatrics (Barcelona, Spain, 2014);

- International Neonatal Associations Conference (Valencia, Spain, 2014);

- $2^{\text {rd }}$ International Congress on Pediatrics Palliative Care (Rome, Italy, 2014);

- St. Sophia Hospital training (Rotterdam, Netherlands, 2014);

- $4^{\text {th }}$ International Conference on Pediatrics Chronic Disease, Disability and Human Development (Jerusalem, Israel, 2015);

- Congress of the European Academy of Pediatrics (Oslo, Norway, 2015);

- $1^{\text {st }}$ Congress of joint European Neonatal Societies (Budapest, Hungary, 2015);

- $1^{\text {st }}$ International Developmental Pediatrics Congress (Istanbul, Turkey, 2015);

- $3^{\text {rd }}$ Congress on Pediatrics Palliative Care (Rome, Italy, 2016);
- $6^{\text {th }}$ Congress of the European Academy of Pediatrics Societies (Geneva, Switzerland, 2016);

- British children's hospice training (London, Great Britain, 2016);

- EPEC-Pediatrics Conference (Montreal, Canada, 2017);

- $15^{\text {th }}$ World Congress of the European Asso-ciation for Palliative Care (Madrid, Spain, 2017);

- $15^{\text {th }}$ International Rare Diseases Conference "Rare Diseases - Open Your Heart and Mind" (Bialobrzegi, Poland, 2017) [10-18].

Now the Infants Orphanage and Kharkiv National Medical University are working on the palliative care, de-institualisation and rehabilitation under the guidance of European Union, IF Renaissance, UNICEF and GIZ (Germany) authorities.

\section{References}

1. Kharkiv regional specialised infants' home ${ }^{1}$. 1/ http://hippocrat.org.ua/

2. Historical reference of the infant's home ${ }^{1} 1$ (1975) Archive of KhRSIH, No.1; 6 p.

3. Benini, F., Drigo, P., Gangemi, M., Sellaroli, V., Lazzarin, P., Jankovic, M., Vecchi, R. (2013). Charter of the rights of the dying child - the trieste charter. Retrieved from: http:// www.fondazionemaruzza.org/en/charter-of-the-rights-of-the-dying-child-the-trieste-charter/

4. Riga, O.O., Marabyan, R.V., Penkov, A. Yu., Osichnyuk, L. M., Drokina, V. M., Konovalova, N. M., Gordienko, ${ }^{2}$. V. (2015). Problems and development prospects of children's palliative care in Ukraine. Family Medicine, 6 (62), 138-140.

5. Penkov, A. Yu., Marabyan, R.V., Riga, O.O. (2015). Respect the right to health individuals of vulnerable groups. Recommendations for the development of children's palliative care Retrieved from: http://khpg.org/index.php?id=1432464675,

http://med-expert.com.ua/media/PM_02_2015/PM_02_2015/assets/basic-html/page11.html.

6. World Health Organization. (?2010)?. WHO model formulary for children 2010. Geneva: World Health Organization. Retrieved from: http://www.who.int/iris/handle/10665/44309

7. Goddard, J. M. (2014). Chronic pain in Children and Young People. Pediatrics and Child Health, 24: 2, 89-91.

8. Riga, O., Marston, J., Penkov, A. (2016). The first experience of mobile pediatric palliative team in Ukraine. Zaporoxhian Medical Journal, 6(99), 62-66.

9. Weaver, M.S., Heinze, K.E., Bell, C.J., Wiener, L. (2016). Establishing psychosocial palliative care standards for children and adolescents with cancer and their families: An integrative review. Palliat Med, 30 (3), 212-223.

10.Riga, O., Gonchar, M., Konovalova, N., Marabyan R. (2016). Outcomes And Need Of Palliative Care For Children With Paralitics Syndrome. $6^{\text {th }}$ Congress of the European Academy of Paediatric Societies, Geneve, 409.

11. Penkov, A., Riga, O., Gonchar, M., Marabyan, R., Shapoval-Deinega, K., Konovalova, N. (2016). "Access To Palliative Care For Children In Ukraine - Challenges And Views". $3^{\text {rd }}$ Congress on Pediatrics Palliative Care, Rome, 112.

12. Makieieva, N., Penkov, A., Marabyan, R., Polyakov, V. (2013). Health and Physical Development: Comparison of Orphanages and Children Living with Birth Parents. Congress EAP, Lyon, 192.

13. Riga, Î ., Gordienko, I., Konovalova, N., Khotsenko, G. (2013). Follow-up of Very Low Birth Weight Infants and Infants with Fetal Alcohol. Abstracy book of Ñongress EAP, Lyon.

14. Riga, Î ., Znamenska, T., Senatorova, G., Kurilina, T., Kondratova, I., Gordienko, I., Kukuruza, G. (2014). Follow-up of Preterm and Term Infants up to Two Years in Kharkiv Regional Perinatal Center. INAC, Valenc ${ }^{3} \mathrm{a}, 122$. 
15.Riga, O., Znamenska, T., Kurilina, T., Kondratova, I., Penkov, A., Gordienko, Kukuruza, G. (2014). Improving Quality Of Care and Rehabilitation of Children with High Perinatal Risk. EAPS, Barselona, 99: Suppl 2 A387 doi: 10.1136 / archdischild - 2014 - 307384. 1075.

16. Riga, O., Znamenska, T., Kurilina, T., Senatorova, G., Penkov, A., Gordienko, I., Kovalova, O. (2015). Follow-up of high risk neonate and Ukrainian National Project "Newlife: New quality of maternity and childhood protection". $4^{\text {th }}$ International Conference on Pediatrics Chronic Disease, Disability and Human Development, Jerusalem, 89.

17.Riga, O., Znamenska, T., Kurilina, T., Senatorova, G., Mavropulo, T., Gordiienko, I., Penkov, A. (2015). Follow Up of High Risk Group Neonates in Different Regions of Ukraine. EAP Congress and Master Course, Oslo, 238.

18.Riga, O., Marabyan, R., Konovalova, N., Iermolaieva, M., Matvieieva, G. (2017). Rare Diseases in Young Children and Pediatrics Palliative Care in Kharkiv region of Ukraine. 15th International Conference on Rare Diseases "Rare Diseases-Open Your Heart and Mind", Bialobrzegi, .37. 